University of Nebraska - Lincoln

DigitalCommons@University of Nebraska - Lincoln

\title{
Water Use Efficiency by Switchgrass Compared to a Native Grass or a Native Grass Alfalfa Mixture
}

J. R. Hendrickson

USDA-ARS, john.hendrickson@ars.usda.gov

Marty R. Schmer

USDA-ARS, University of Nebraska-Lincoln, marty.schmer@ars.usda.gov

Matt A. Sanderson

USDA-ARS, Matt.sanderson@ars.usda.gov

Follow this and additional works at: https://digitalcommons.unl.edu/usdaarsfacpub

Hendrickson, J. R.; Schmer, Marty R.; and Sanderson, Matt A., "Water Use Efficiency by Switchgrass Compared to a Native Grass or a Native Grass Alfalfa Mixture" (2013). Publications from USDA-ARS / UNL Faculty. 1297.

https://digitalcommons.unl.edu/usdaarsfacpub/1297

This Article is brought to you for free and open access by the U.S. Department of Agriculture: Agricultural Research Service, Lincoln, Nebraska at DigitalCommons@University of Nebraska - Lincoln. It has been accepted for inclusion in Publications from USDA-ARS / UNL Faculty by an authorized administrator of DigitalCommons@University of Nebraska - Lincoln. 


\title{
Water Use Efficiency by Switchgrass Compared to a Native Grass or a Native Grass Alfalfa Mixture
}

\author{
J. R. Hendrickson • M. R. Schmer • M. A. Sanderson
}

This article is a U.S. government work, and is not subject to copyright in the United States.

Published online: 15 January 2013

(C) Springer Science+Business Media New York (outside the USA) 2013

\begin{abstract}
Perennial grass systems are being evaluated as a bioenergy feedstock in the northern Great Plains. Inter-annual and inter-seasonal precipitation variation in this region will require efficient water use to maintain sufficient yield production to support a mature bioenergy industry. Objectives were to evaluate the impact of a May-June (early season) and a July-August (late season) drought on the water use efficiency (WUE), amount of water used, and biomass production in monocultures of switchgrass (Panicum virgatum L.), western wheatgrass (Pascopyrum smithii (Rydb.) Á. Löve), and a western wheatgrass-alfalfa (Medicago sativa L.) mixture using an automated rainout shelter. WUE was strongly driven by biomass accumulation and ranged from 5.6 to $7.4 \mathrm{~g}$ biomass $\mathrm{mm}^{-1}$ water for switchgrass to 1.06 to $2.07 \mathrm{~g}$ biomass $\mathrm{mm}^{-1}$ water used with western wheatgrass. Timing of water stress affected WUE more in western wheatgrass and the western wheatgrass-alfalfa mixture than switchgrass. Water deficit for the western wheatgrass-alfalfa mixture was $23 \%$ lower than western wheatgrass $(P=0.0045)$ and $31 \%$ lower than switchgrass $(P<0.0001)$ under the May-June stress water treatment, while switchgrass had a 37 and $38 \%$ greater water deficit than did western wheatgrass or western wheatgrass-alfalfa mixture, respectively $(P<0.001)$ under the July-August water stress treatment. Water depletion was always greatest in the upper $30 \mathrm{~cm}$. Switchgrass had greater WUE but resulted in greater soil water depletion at the end of the growing season
\end{abstract}

U.S. Department of Agriculture, Agricultural Research Service, Northern Plains Area is an equal opportunity/affirmative action employer, and all agency services are available without discrimination.

J. R. Hendrickson $(\bowtie) \cdot$ M. A. Sanderson

Northern Great Plains Research Laboratory, USDA-Agricultural Research Service, P.O. Box 459, Mandan, ND 58554, USA

e-mail: john.hendrickson@ars.usda.gov

M. R. Schmer

Agroecosystem Management Research Unit, USDA-Agricultural Research Service, University of Nebraska, 137 Keim Hall, Lincoln, NE 68583, USA compared to western wheatgrass and a western wheatgrassalfalfa mixture which may be a concern under multi-year drought conditions.

Keywords Drought · Western wheatgrass $\cdot$ Soil water deficit . Rainout shelter

\section{Introduction}

Globally, agriculture is the largest user of freshwater resources $[1,2]$, and there are concerns about how biofuel production may impact water consumption and quality [3]. As human population grows resulting in increased demand for fresh water, there will be increased emphasis on water use efficiency (WUE) in biomass production [4]. In the semiarid northern Great Plains, annual productivity of agricultural systems is largely driven by precipitation. Sustainability in the region depends on efficient use of water [5] which is often expressed as WUE or the measure of crop production per unit of water input. Water inputs, in dryland cropping systems, are either stored soil water or precipitation and so WUE can be defined as crop production divided by soil water used plus precipitation [5]. Although WUE primarily has been evaluated in traditional agronomic crops, it can also impact the potential for developing cellulosic biofuels. Therefore, defining WUE of potential cellulosic bioenergy crops is important in developing a sustainable biofuel industry.

Seasonality of precipitation can have important impacts on production. Precipitation in the Great Plains has always been characterized by large inter- and intra-annual variability with high levels of uncertainty in amount and timing of received precipitation [6]. Furthermore, future climate scenarios indicate even more variability in rainfall in the region [7, 8]. Grasslands have the capacity for large increases in biomass in response to high precipitation levels [9] in humid regions, but biomass changes may be more limited at the community level in a semi-arid environment [10]. Seasonality of precipitation can 
also influence relative abundance of functional groups such as C4 grass species [11] which means predicting ecosystem response to climate change needs to include rainfall timing as well as amount [7].

There are several perennial grasses in monocultures or in mixtures that are currently being evaluated as potential bioenergy feedstocks in the northern Great Plains. There has been a serious effort to develop switchgrass as a cellulosic bioenergy crop since the early 1990s [12]. Managed switchgrass monocultures were estimated to produce $540 \%$ more energy than non-renewable energy consumed [13]. Western wheatgrass is a dominant native grass in the northern mixed grass prairie [14] and is being evaluated as a bioenergy feedstock based on its adaptability and stable biomass yields in this region. Alfalfa is often used in grass mixtures to improve biomass yield, quality, and seasonal distribution [15]. Alfalfa also can replace external nitrogen fertilization when grown in binary mixtures with grass [16] and can increase overall productivity with no evidence of a decline in grass yield when interseeded into a rangeland [17].

Warm-season or $\mathrm{C}_{4}$ grasses such as switchgrass generally have higher WUE than do cool-season $\mathrm{C}_{3}$ grasses such as western wheatgrass $[18,19]$. However, other factors besides photosynthetic pathway affect WUE. Switchgrass biomass production is strongly driven by precipitation, but as precipitation increases, WUE decreases [20]. Precipitation variability can impact switchgrass WUE and yields [21]. In cool-season grasses, WUE was strongly correlated with biomass production [22]. Western wheatgrass was reported to have greater drought tolerance than crested wheatgrass [Agropyron cristatum (L.) Gaertn.] [23], although western wheatgrass had a lower WUE [24]. This may be related to western wheatgrass's slower but more stable growth pattern [24]. Dryland alfalfa was reported to have greater water use efficiency than crested wheatgrass [25] which indicates alfalfa's WUE should be greater than that of western wheatgrass. Alfalfa WUE also increased with increases in available soil water [26]. Alfalfa can extract soil water to $2.7 \mathrm{~m}$ [27] which makes it very drought tolerant. There is limited information available regarding WUE of grass and legume mixtures. Høgh-Jensen and Schjoerring [28] reported that perennial ryegrass (Lolium perenne L.) in a white clover (Trifolium repens L.)-ryegrass mixture had lower WUE than ryegrass in pure stands, but white clover WUE was greater in a mixture than in a pure stand. These different responses were attributed to $\mathrm{N}$ limitation in the ryegrass.

Understanding WUE and how it may be influenced by precipitation timing is critical in developing sustainable cellulosic biofuel systems. We compared the WUE of switchgrass, a native warm-season grass that is a commonly recognized cellulosic biofuel, to western wheatgrass, a native cool-season grass that is indicative of the plant community of the northern Great Plains, and a binary mixture of western wheatgrass and alfalfa, which is a common producer strategy to improve yields with limited inputs. Because of the regional inter-annual variability and the differing impacts precipitation timing can have on different photosynthetic pathways, we also evaluated the influence of an early (May-June) and a late (July-August) growing season drought on WUE. We hypothesized the early season drought would have a greater impact on western wheatgrass and the binary mixture and the late season drought would have a greater impact on switchgrass.

\section{Materials and Methods}

\section{Study Site}

This study was conducted in 2006 and 2007 at the Northern Great Plains Research Laboratory located near Mandan, North Dakota, USA $\left(100^{\circ} 54^{\prime} 56^{\prime \prime} \mathrm{W}, 46^{\circ} 48^{\prime} 29^{\prime \prime} \mathrm{N}\right)$. The climate is characterized as semiarid continental [29] with cold winters and hot summers. Average annual precipitation and air temperature (1913 to 2012) is $416 \mathrm{~mm}$ and $5.3^{\circ} \mathrm{C}$, respectively. A majority of the precipitation ( $259 \mathrm{~mm}$ or $62 \%$ ) falls between May and August which are the primary growing months. An evaluation of 94 years of precipitation data from the study site, from the first complete year of data (1914) till the year after the study ended (2008), indicated that approximately $30 \%$ of the years were drier than the long-term average in either May-June or July-August, but these dry periods were either preceded by or followed by normal or above normal precipitation.

An $11.5 \times 30.3-\mathrm{m}$ rainout shelter [30] established on a Parshall fine sandy loam (coarse-loamy, mixed Pachic Haploborolls) was used in this study. Electric motors propel the shelter over the plots when sensors detect rainfall. An overhead sprinkler irrigation system was installed under the shelter to apply water treatments. Soil water measurements were taken using a neutron scattering probe (503DR Hydroprobe, CPN Corp) to a depth of $1.8 \mathrm{~m}$ at $0.3-\mathrm{m}$ increments before water treatments were applied and after a killing frost in autumn of each year.

\section{Treatment Descriptions}

This experiment was designed as a completely randomized design. Area under the rainout shelter was divided into six, $7.8 \times 3.9-\mathrm{m}$ plots (main plots). Each plot was randomly assigned to one of three different water treatments (WATER), and each treatment was replicated twice. Since a majority of precipitation in the region is received between May and $\mathrm{Au}-$ gust, water treatments focused on manipulating precipitation during that period. Water treatments were a CONTROL, with amounts of simulated precipitation water applied to mimic monthly precipitation totals from May through August and two drought treatments, May-June and July-August, where 
only $50 \%$ of the May-August precipitation was applied to the plots. The difference between the drought treatments was when the limited irrigation water was applied. In the May-June treatment, $20 \%$ of the limited irrigation water was applied in May and June with the remainder (80\%) applied in July and August. In the July-August treatment, the reverse was true. Twenty percent of the irrigation water was applied in July and August with $80 \%$ being applied in May and June.

Water treatments were applied in 2006, while in 2007 water treatments were more similar to long-term precipitation patterns from May through August. An equipment failure during an electrical storm in June 2007 prevented the rainout shelter from closing. The result was that the drought treatments received approximately $90 \%$ of their water for the season from rainfall during the storm. An analysis of long-term (1913-2000) US Weather Service data from the Northern Great Plains Research Laboratory indicated that only $6 \%$ of the total years of record had two dry years in a row, so a decision was made not to apply water treatments in 2007 but to reestablish the long-term average moisture regime.

Each plot was then divided into three $2.2 \mathrm{~m} \times 3.9-\mathrm{m} \mathrm{sub}-$ plots seeded to different species or species combinations (SPECIES). SPECIES treatments were: "Sunburst" switchgrass, "Rodan" western wheatgrass, or a western wheatgrass _ "Vernal" alfalfa mixture. Grasses were seeded at a rate of 30 seeds per $30.5 \mathrm{~cm}$ of row into $3.9 \mathrm{~m}$ long rows $0.3 \mathrm{~m}$ apart on May 30, 2003. Alfalfa was seeded into mixture plots in 2.2-m rows perpendicular to the grass rows 1 week after sowing the grasses at a rate of 12 per seeds per $30.5 \mathrm{~cm}$ of row. Alfalfa rows were also on $0.3 \mathrm{~m}$ row spacing. A control plot where plant material was harvested following an autumn killing frost was used to determine end of season biomass. Biomass was estimated by harvesting two $0.05-\mathrm{m}^{2}$ rectangular plots to ground level in the autumn. Biomass samples were ovendried at $55{ }^{\circ} \mathrm{C}$ until a constant weight was reached. Biomass yields are reported on a dry matter basis.

\section{Water Use}

Access tubes were installed in the center of each $2.2 \times 3.9-\mathrm{m}$ sub-plot, for soil moisture measurements via a neutron probe. Soil water measurements were taken to a depth of $1.8 \mathrm{~m}$ at 0.3 $\mathrm{m}$ increments before simulated precipitation was started, after the killing frost in the autumn and at roughly 2-week intervals during the growing season (May-August).

Water use efficiency (WUE) was measured by modifying the formula for estimating system water use efficiency by Peterson et al. [5]. The modified formula was:

WUE $=$ biomass $/(\mathrm{I}-$ water $-\mathrm{F}-$ water + IRR $)$

where biomass=end-of-season biomass (dry matter yield), $I$-water $=$ soil water prior to initial irrigation (soil water at planting), $F$-water=soil water after killing frost (soil water at harvest), $I R R=$ May-to-August irrigation (growing season precipitation), and names in parentheses correspond to the terminology in the original formula [5]. The formula was developed for annual crops, and therefore, soil water at planting would be more closely related to soil water at greenup for perennial species.

We calculated water deficits as the difference in soil water between the date of the greatest water accumulation in the soil profile to the date of the least water in the soil profile similar to Merrill et al. [31]. In 2006, water deficits were calculated using the entire $1.8-\mathrm{m}$ soil profile to determine dates with the most and least available water for each species and water treatment. Water deficits were then calculated for each $0.3-\mathrm{m}$ soil increments by subtracting minimum available water from maximum available water for each species and water treatment. Water deficit data were analyzed for each species and depth within a water treatment.

\section{Statistical Analysis}

The study was analyzed as a split plot with water treatment being the main plot factor and species being the sub-plot factor. Data were analyzed using PROC MIXED in SAS [32] with water, species, and year considered as fixed affects, and replication was considered as a random effect. Repeated measures analysis with an unstructured covariance structure was used to evaluate differences between water deficits by soil depth. Biomass yields were log transformed for normality. Means were separated using a Tukey mean separations using $P \leq 0.10$ to determine significant differences. Actual $P$ values for significance are given in the text where appropriate.

\section{Results}

Irrigation Application

The water treatments were designed to test the impact of drought stress at different critical periods during the growing season. In 2006, irrigation water applied during the May-June treatment was only $23 \%$ of the control for May and June (Table 1). A similar pattern emerged with the JulyAugust treatment where applied irrigation was $20 \%$ of the control for July and August (Table 1). Irrigation water applied to the July-August treatment plots in May and June was $88 \%$ of the control, and simulated precipitation applied to the May-June treatment plots in July and August was $77 \%$ of the control (Table 1). Total simulated precipitation plus naturally occurring moisture applied to the May-June plots in 2006 was $68 \%$ of the control and $71 \%$ of the control for the July-August treatment plots (Table 1). In 
Table 1 Precipitation totals by month in 2006 and 2007 for each water treatment and the long-term (1913-2010) average

January February March April May June July August September October November December Total $\mathrm{mm}$

2006

\begin{tabular}{lccccccccccccc} 
Control & 1.78 & 3.56 & 9.14 & 24.13 & 57.91 & 57.91 & 49.53 & 66.04 & 38.10 & 40.13 & 1.27 & 17.27 & 366.78 \\
May-June drought & 1.78 & 3.56 & 9.14 & 24.13 & 13.21 & 13.21 & 38.1 & 50.80 & 38.10 & 40.13 & 1.27 & 17.27 & 250.70 \\
July-August drought & 1.78 & 3.56 & 9.14 & 24.13 & 50.80 & 50.80 & 9.91 & 13.21 & 38.10 & 40.13 & 1.27 & 17.27 & 260.10 \\
2007 & & & & & & & & & & & & & \\
Control & 3.30 & 15.75 & 29.92 & 17.02 & 57.91 & 90.68 & 58.42 & 67.31 & 40.89 & 12.70 & 1.78 & 4.06 & 396.75 \\
May-June drought & 3.30 & 15.75 & 29.92 & 17.02 & 13.21 & 79.50 & 76.20 & 78.74 & 40.89 & 12.70 & 1.78 & 4.06 & 396.75 \\
July-August drought & 3.30 & 15.75 & 29.92 & 17.02 & 50.80 & 88.90 & 63.50 & 67.31 & 40.89 & 12.70 & 1.78 & 4.06 & 396.75 \\
Long term & 9.40 & 9.91 & 16.76 & 35.56 & 57.67 & 87.12 & 66.29 & 46.74 & 36.32 & 26.16 & 13.97 & 9.40 & 416.31 \\
\hline
\end{tabular}

Monthly precipitation data were the same across treatments in January, February, March, April, September, October, November, and December. Totals for May through August were from applied using irrigation

2007, irrigation water applied was the same for all water treatments. In order to make sure the all water treatments got the same amount during the season, we adjusted July and August irrigation as needed (Table 1).

\section{Water Use Efficiency}

The WUE and the amount of water used both had a year by water interaction (Table 2). Because of the year by water interaction and the strong $F$ values for year, we analyzed WUE and the amount of water used by year. Since WUE is comprised of end of season biomass and the amount of water used, we also analyzed end of season biomass by year.

In 2006, WUE had a water by species interaction. There were no differences in WUE between species for the control treatment (Fig. 1). However, for both of the May-June and July-August treatments, western wheatgrass had a lower WUE than switchgrass. The WUE for the western wheatgrass-alfalfa mixture was similar to switchgrass in the May-

Table $2 F$ values for water use efficiency (WUE), amount of water used, and biomass yield

\begin{tabular}{llll}
\hline Effect & WUE & $\begin{array}{l}\text { Amount of } \\
\text { water used }\end{array}$ & $\begin{array}{l}\text { Biomass } \\
\text { yield }^{\mathrm{a}}\end{array}$ \\
\hline Year & $12.9^{* *}$ & $44,511.1^{* * *}$ & $3.3 * * * *$ \\
Species & $40.6^{* *}$ & 1.0 & $45.5^{*}$ \\
Year $\times$ species & $4.7^{*}$ & $21.2^{* * *}$ & 2.3 \\
Water & 2.3 & $1,537.4^{* * *}$ & 0.2 \\
Year $\times$ water & $4.1^{*}$ & $2,873.7^{* * *}$ & 0.4 \\
Species $\times$ water & 1.7 & 1.1 & 1.3 \\
Year $\times$ species $\times$ water & 1.2 & 2.5 & 0.5 \\
\hline
\end{tabular}

Effects considered in the model include year, vegetation species, and water treatment

$* P<0.05 ; * * P<0.01 ; * * * P<0.001 ; * * * * P<0.10$

${ }^{\text {a }}$ Data were log-transformed
June treatment plots and was similar to western wheatgrass in the July-August treatment (Fig. 1). There were also differences in WUE between water stress treatments within a species (Table 2). The WUE for both the May-June and JulyAugust treatments were significantly greater than the control in western wheatgrass. The WUE for the May-June treatment was greater than the WUE for the control in the western wheatgrass-alfalfa mixture (Table 3). In 2007, there was not a significant interaction, but WUE for western wheatgrass was lower than the WUE for either switchgrass or the western wheatgrass-alfalfa mixture (Fig. 2).

\section{Water Use}

The amount of water used differed among water treatments and among species in both 2006 and 2007, but there was not a

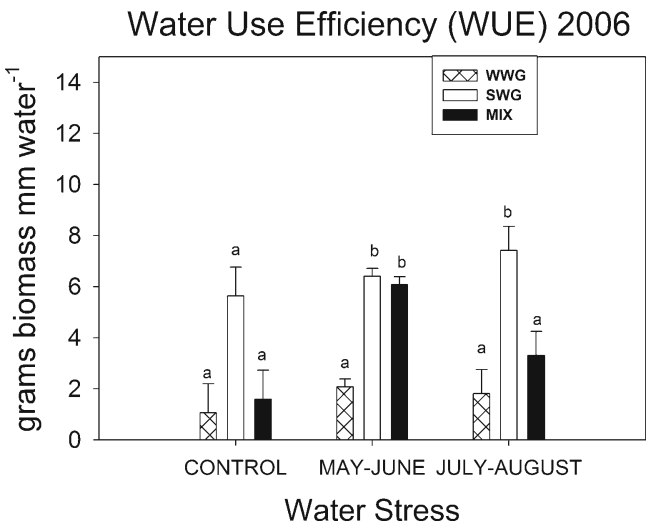

Fig. 1 Water use efficiency (WUE) of western wheatgrass $(W W G)$, switchgrass $(S W G)$, and a western wheatgrass-alfalfa mixture (MIX) under different periods of water stress in 2006. Control indicated normal precipitation from May through August, May-June indicated $50 \%$ of normal precipitation in May-June but normal precipitation in July and August, and July-August indicated normal precipitation for May-June but $50 \%$ of normal for July and August. Letters above bars indicate significant differences between species within a water stress treatment at $P \leq 0.10$ 
Table 3 Water use efficiency (WUE, grams biomass per millimeter of water) of three water treatments within species for 2006

Water stress treatment Species

\begin{tabular}{lll}
\hline Western & Switchgrass & Western \\
wheatgrass & & $\begin{array}{l}\text { wheatgrass-alfalfa } \\
\text { mixture }\end{array}$
\end{tabular}

WUE

$\begin{array}{llll}\text { Control } & 1.07 \mathrm{a} & 5.64 \mathrm{a} & 1.60 \mathrm{a} \\ \text { May-June } & 2.08 \mathrm{~b} & 6.41 \mathrm{a} & 6.08 \mathrm{~b} \\ \text { July-August } & 1.82 \mathrm{~b} & 7.42 \mathrm{a} & 3.31 \mathrm{ab} \\ \text { Standard errors } & 0.21 & 1.34 & 1.0\end{array}$

Letters following numbers within columns indicate significant differences between water stress treatments within a species $(P<0.10)$

water by species interaction. For a majority of species and water treatment combinations, soil water was greatest on April 21 and least on September 21. There were occasional deviations with May 18 being another date with most available water and August 24 and September 6 as dates with least available water. In 2006, the amount of water used in the control treatment was greater than May-June and July-August treatments, and the May-June water stress treatment used more water than the July-August water treatment (Table 4). In 2007, The MayJune water treatment used significantly less water than did either the control or the July-August treatment (Table 4). In 2006, switchgrass used significantly more water than either western wheatgrass or the western wheatgrass-alfalfa mixture (Table 4). In 2007, the western wheatgrass-alfalfa mixture used significantly more water than switchgrass (Table 4 ).

\section{End of Season Biomass}

There was a water by species interaction for end of season biomass in 2006. There were no differences among species for

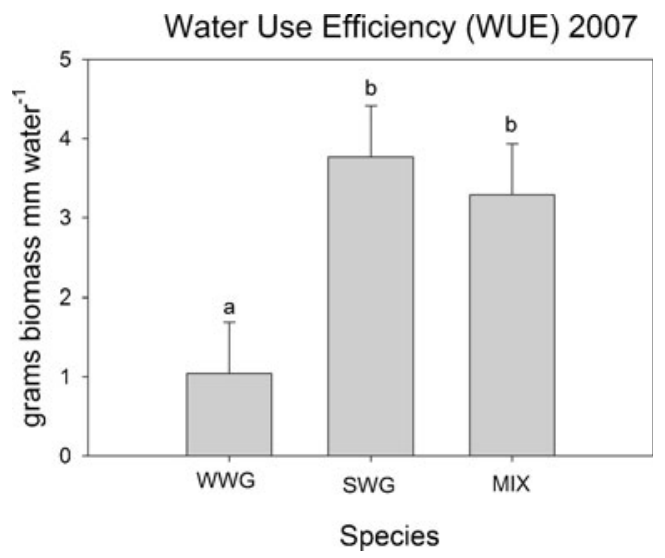

Fig. 2 Water use efficiency (WUE) for western wheatgrass $(W W G)$, switchgrass $(S W G)$, and a binary mixture of western wheatgrass-alfalfa $(M I X)$ in 2007. Letters above bars indicate significant differences at $P \leq 0.10$
Table 4 Amount of water used (millimeters) under three water regimes by different species in 2006 and 2007

\begin{tabular}{|c|c|c|c|}
\hline \multicolumn{2}{|l|}{ Water regime } & \multicolumn{2}{|l|}{ Species } \\
\hline \multicolumn{4}{|c|}{2006 (mm of water used) } \\
\hline Control & $247.1 \mathrm{a}$ & Western wheatgrass & $173.5 \mathrm{~b}$ \\
\hline May-June drought & $141.5 \mathrm{~b}$ & Switchgrass & $176.6 \mathrm{a}$ \\
\hline July-August drought & $132.5 \mathrm{c}$ & $\begin{array}{l}\text { Western wheatgrass- } \\
\text { alfalfa mixture }\end{array}$ & $171.1 \mathrm{~b}$ \\
\hline Standard errors & 1.2 & & 1.0 \\
\hline \multicolumn{4}{|c|}{2007 (mm of water used) } \\
\hline Control & $308.2 \mathrm{a}$ & Western wheatgrass & $295.7 \mathrm{ab}$ \\
\hline May-June drought & $273.8 \mathrm{~b}$ & Switchgrass & $293.5 \mathrm{~b}$ \\
\hline July-August drought & $304.2 \mathrm{a}$ & $\begin{array}{l}\text { Western wheatgrass- } \\
\text { alfalfa mixture }\end{array}$ & $297.0 \mathrm{a}$ \\
\hline Standard errors & 1.9 & & 1.1 \\
\hline
\end{tabular}

Different letters by column denote differences $(P<0.10)$ between water regimes or species within year

end of season biomass for the control water treatment in 2006 (Fig. 3). There were differences among species in end of season biomass for the May-June treatment $(P=.0735)$ and for the July-August treatment $(P=.0153)$. End of season biomass for western wheatgrass was lower than for switchgrass or the western wheatgrass alfalfa mixture in the May-June treatment, and end of season biomass for both western wheatgrass and the western wheatgrass-alfalfa mixture was lower than for switchgrass under the July-August water treatment (Fig. 3).

\section{Soil Water Deficit}

Soil water deficit was evaluated for each water treatment. There were no significant differences among species for control plots,

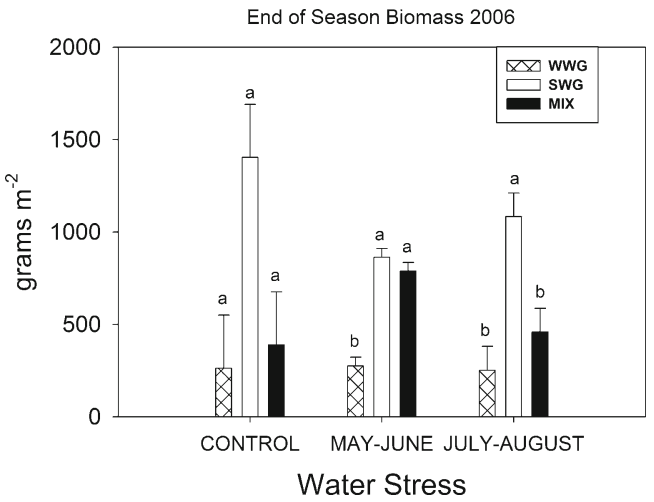

Fig. 3 End of season biomass produced by western wheatgrass $(W W G)$, switchgrass $(S W G)$, and a western wheatgrass-alfalfa mixture $(M I X)$ under different periods of water stress in 2006. Control indicated normal precipitation from May through August, May-June indicated $50 \%$ of normal precipitation in May-June but normal precipitation in July and August, and July-August indicated normal precipitation for May-June but $50 \%$ of normal for July and August. Letters above bars indicate significant differences between species within a water stress treatment at $P \leq 0.10$ 
but the water deficit for the western wheatgrass-alfalfa mixture was lower than western wheatgrass $(P=0.0045)$ or switchgrass $(P<0.0001$; Fig. 4a) under the May-June water treatment. Switchgrass had a greater water deficit than did either western wheatgrass or the western wheatgrass-alfalfa mixture $(P<0.0001)$ under the July-August water treatment (Fig. 4a).

There were differences in water deficit between soil depths for each of the water treatments averaged across species. Under the control water treatment, the $0.3-\mathrm{m}$ depth had a greater water deficit than did the $1.8-\mathrm{m}$ depth $(P=0.0590$; Fig. $4 \mathrm{~b}$ ). Under the May-June water treatment, the 0.3- and $0.6-\mathrm{m}$ depths had significantly greater water deficits than the rest of the depths. The 1.2-m depth had a significantly greater water deficit than the 1.5- or 1.8-m depths, and the 0.9- and 1.5-m depths had significantly greater water deficits than did the $1.8-\mathrm{m}$ depths under the May-June water treatment (Fig. 4b). Under the July-August water treatment, the $0.3-\mathrm{m}$ depth had a greater water deficit than did the other depths, the 0.6- $\mathrm{m}$ depth had a greater water deficit than did the all the other depths except $0.3 \mathrm{~m}$, and the 0.9-, 1.2-, and 1.5-m depths had a greater water deficit than did the 1.8-m depth (Fig. 4b).

\section{Discussion}

Developing a sustainable cellulosic bioenergy production system requires information on how efficiently potential bioenergy plants use water especially in semi-arid regions.
Fig. 4 Soil water deficits for a western wheatgrass $(W W G)$, switchgrass $(S W G)$, and a western wheatgrass-alfalfa mixtures $(M I X)$ grown under different periods of water stress in 2006 and $\mathbf{b}$ across species within depth increments. Control indicated normal precipitation from May through August, May-June indicated $50 \%$ of normal precipitation in May-June but normal precipitation in July and August, and July-August indicated normal precipitation for May-June but $50 \%$ of normal for July and August. Letters above bars in (a) indicate significant differences between species within a water stress treatment at $P \leq 0.10$. Letters beside bars in (b) indicate significant differences between soil depths within water stress treatments at $P \leq 0.10$
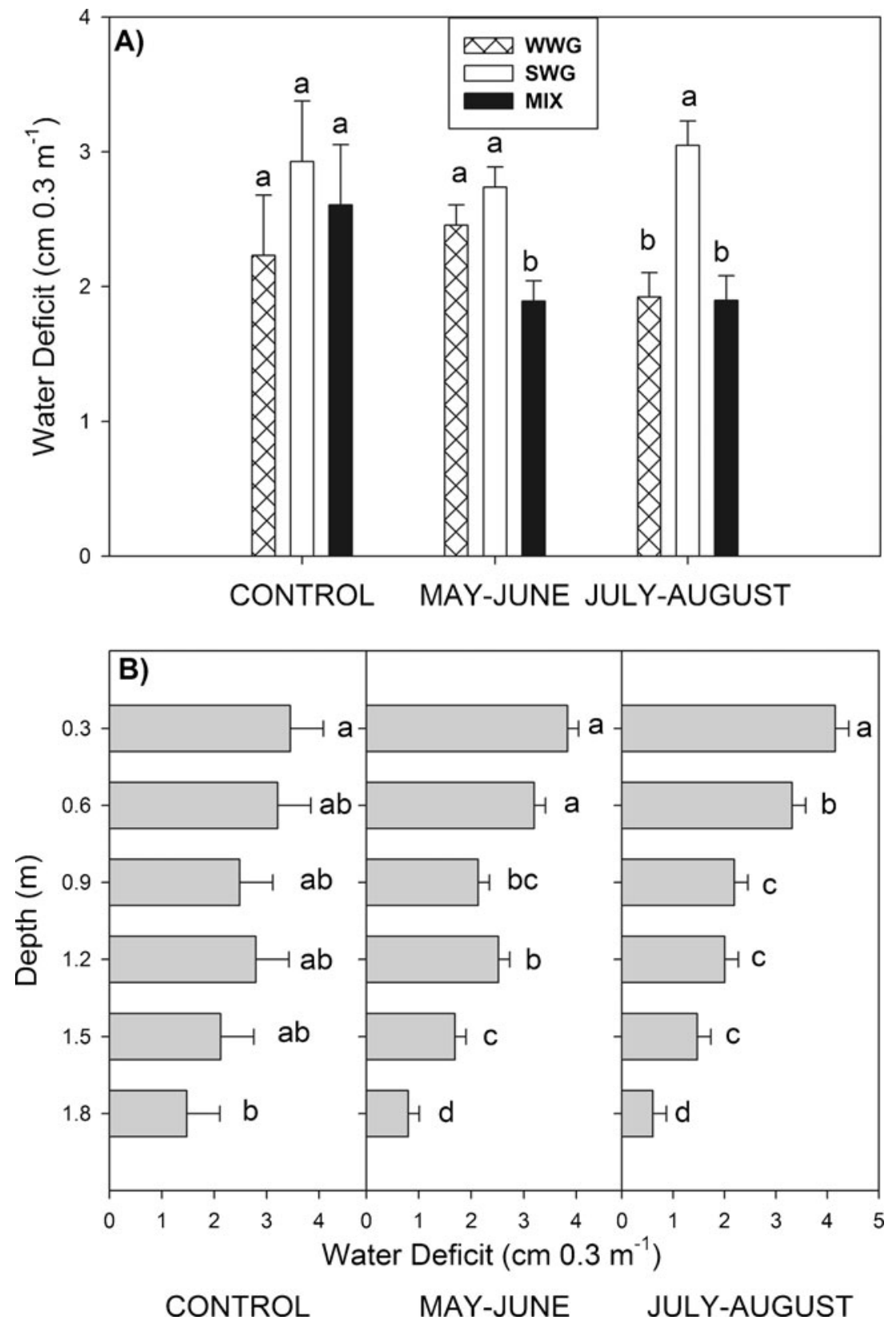
We compared WUE in switchgrass, a major potential cellulosic bioenergy crop, to western wheatgrass, a dominant native perennial grass in the Great Plains, and a western wheatgrass-alfalfa mixture. We hypothesized that season of water stress would affect WUE and water use, and these effects would change with species. We found that (1) switchgrass had three to four times the WUE of western wheatgrass, (2) binary mixtures of western wheatgrass and alfalfa had a WUE similar to that for switchgrass under certain drought conditions, and (3) switchgrass produced greater water deficits in the soil than did western wheatgrass and western wheatgrass-alfalfa. Seasonality of water stress affected the cool-season perennials (western wheatgrass and western wheatgrass-alfalfa) but not switchgrass.

\section{Water Use Efficiency}

One way to enhance WUE is to improve the transpiration use efficiency [1] which would either require producing more biomass with the same amount of water or use less water to produce the same biomass. Biomass differences were the drivers of WUE in our study. Differences in end of season biomass in 2006 mirrored the differences in WUE.

Our study also supported the view that $\mathrm{C}_{4}$ species have greater WUE than $\mathrm{C}_{3}$ species $[33,34]$. In both 2006 and 2007, the WUE of switchgrass, a $\mathrm{C}_{4}$ grass, was generally more than three times greater than western wheatgrass, a $\mathrm{C}_{3}$ grass (Table 1). The WUE for switchgrass ranged from 5.6

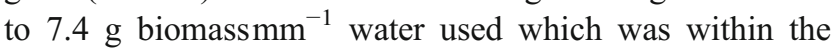
range of the 3 to $8 \mathrm{~g}$ biomass $\mathrm{mm}^{-1}$ water used reported by Koshi et al. [35] for different harvest and moisture regimes. The western wheatgrass monoculture WUE ranged from 1.1 to $2.1 \mathrm{~g}$ biomass $\mathrm{mm}^{-1}$ water used which was similar to the $1.2 \mathrm{~g}$ biomass $\mathrm{mm}^{-1}$ water used reported by Frank and Bauer [24]. The limited information on the WUE of binary mixtures and available reports focused on individual components of the mixture [28]. Therefore, our information is some of the first WUE information on binary mixtures as a whole.

Adding alfalfa to western wheatgrass increased WUE (Figs. 1 and 2). It was expected that alfalfa and western wheatgrass would be most detrimentally affected by the May-June water stress period which is the main growing period for cool-season plants in the region. However, WUE for the western wheatgrass-alfalfa mixture under May-June water stress in 2006 and for all of 2007 was very close to that of switchgrass. Incorporating alfalfa into wheatgrass increased biomass yields as reported elsewhere [16]. Legumes that grow over longer periods can improve the seasonal availability of forages into the latter parts of growing seasons [15]. Both factors enhanced WUE of the western wheatgrass-alfalfa mixture and lowered the impact of the May-June stress treatment.
Our data suggested that timing of water stress affected WUE in western wheatgrass and the western wheatgrassalfalfa mixture but not in switchgrass. Previous reports have suggested that WUE in western wheatgrass did not change with water stress, potentially because western wheatgrass maintains slow levels of growth during drought periods [24]. In contrast, switchgrass has been reported to be impacted by changes in water availability. Earlier reports [20, 35 ] indicated that WUE declines with increased water availability in switchgrass. Stout et al. [21] indicated soil attributes, such as water holding capacity, make the largest contribution to WUE in switchgrass under variable precipitation scenarios. Soils under the rainout shelter were fine sandy loams [36] with a low water holding capacity, and simulated precipitation was done on a regular basis. Switchgrass plants are deep-rooted [37] and so switchgrass could have partially adjusted to the lower amount of water received under water stress treatments.

\section{Soil Water Deficit}

We calculated soil water deficit by depth as the difference in soil water between the date of the greatest water accumulation in the soil profile to the date of the least water in the soil profile similar to Merrill et al. [31]. Switchgrass had greater soil water deficit than the binary mixture under both water stress treatments. Switchgrass roots are widely distributed in deeper soil horizons than cool-season grasses [38, 39]. However, alfalfa was shown to deplete soil water to a greater extent than other $\mathrm{C}_{3}$ perennial grasses or wheat (Triticum aestivum L.) [25]. Greater switchgrass biomass could have resulted in greater transpiring leaf area which has been linked to increase water use [40], and greater water use can increase soil water deficit. Alternatively, water stress has been reported to lower transpiration in alfalfa and thereby increase WUE [41]. This may explain why the WUE of the binary alfalfa-grass mixture was similar to switchgrass under the May-June water stress treatment.

There were also differences between water stress treatments in soil water deficit by depth (Fig 4). Soil water deficit for each of the six depths was more similar within control treatment than for the other two water treatments (Fig 4). Soil water deficit for all three water treatments was greatest in the upper $30 \mathrm{~cm}$ where a majority of the roots are generally located [42]. Drought can result in root mortality, and for both perennial grasses [43] and alfalfa [44], root mortality generally occurs in the surface layer. The potential for increased mortality under water stress in the surface layer and the wide distribution of both switchgrass $[38,39]$ and alfalfa [45] roots into deeper soil horizons make the significant differences in water depletion at different depths somewhat surprising. 


\section{Conclusions}

We found that switchgrass had three to four times the WUE of the common dominant native perennial grass, western wheatgrass, which suggests that switchgrass would be an appropriate cellulosic biofuel crop in semi-arid areas. Binary mixtures with legumes may be one way to improve WUE in $\mathrm{C}_{3}$ grasses; however, in our study, inclusion of alfalfa with western wheatgrass resulted in more variable WUE during periods of water stress compared to switchgrass. Although switchgrass had greater WUE, it also showed a greater soil water deficit compared to western wheatgrass and the western wheatgrass-alfalfa mixture. Although this is a positive attribute in a single dry year, this may be of concern if switchgrass is periodically rotated into annual crop production or if a multi-year drought occurs.

Acknowledgments The authors would like to acknowledge M.K. Tokach, B. Boehm, M. Hatzenbuhler, and D. Krein for care and maintenance of the automated rainout shelter. C. Gundmundsen, C. Sand, and A. Fischer were instrumental in data collection. The authors would also like to thank J. Halvorson, R. Mitchell, and B. Northup for reviews of earlier versions of the manuscript.

\section{References}

1. Wallace JS (2000) Increasing agricultural water use efficiency to meet future food production. Agric Ecosyst Environ 82:105119

2. Haekstra AY, Chapagain AK (2007) Water footprints of nations: water use by people as a function of their consumption pattern. Water Resour Manage 21:35-48

3. Dominguez-Faus R, Powers SE, Burken JG, Alvarez PJ (2009) The water footprint of biofuels: a drink or drive issue? Environ Sci Technol 43:3005-3010

4. Jǿrgensen U, Schelde K (2001) Energy crop water and nutrient efficiency. The International Energy Agency IEA Bioenergy Task 17, Short Rotation Crops.

5. Peterson GA, Schlegel AJ, Tanaka DL, Jones OR (1996) Precipitation use efficiency as affected by cropping and tillage systems. J Prod Agric 9:180-186

6. Schneider JM, Garbrecht JD (2003) A measure of the usefulness of seasonal precipitation forecasts for agricultural applications. Trans ASAE 46:257-267

7. Craine JM, Nippert JB, Elmore AJ, Skibbe AM, Hutchinson SL (2012) Timing of climate variability and grassland productivity. PNAS 109:3401-3405

8. USGCRP (2008) Regional climate impacts: Great Plains. www.globalchange.gov/images/cir/pdf/great-plains.pdf. Accessed 08 Jul 2012.

9. Knapp AK, Smith MD (2001) Variation among biomes in temporal dynamics of aboveground primary production. Science 291:481484

10. Derner JD, Hickman KR, Polley HW (2011) Decreasing precipitation variability does not elicit major aboveground biomass or plant diversity responses in a mesic rangeland. Rangeland Ecol Manage 64:352-357
11. Paruelo JM, Lauenroth WK (1996) Relative abundanace of plant functional types in grasslands and shrublands of North America. Ecol Appl 6:1212-1224

12. McLaughlin SB, Kszos LA (2005) Development of switchgrass (Panicum virgatum) as a bioenergy feedstock in the United States. Biomass Bioenerg 28:515-535

13. Schmer MR, Vogel KP, Mitchell RB, Perrin RK (2008) Net energy of cellulosic ethanol from switchgrass. PNAS 105:464-469

14. Barker WT, Whitman WC (1988) Vegetation of the Northern Great Plains. Rangelands 10:266-272

15. Sleugh B, Moore KJ, George JR, Brummer EC (2000) Binary legume-grass mixtures improve forage yield, quality, and seasonal distribution. Agron J 92:24-29

16. Berdahl JD, Karn JF, Hendrickson JR (2001) Dry matter yields of cool-season grass monocultures and grass-alfalfa binary mixtures. Agron J 93:463-467

17. Hendrickson JR, Liebig MA, Berdahl JD (2008) Responses of Medicago sativa and $M$. falcata type alfalfas to different defoliation times and grass competition. Can J Plant Sci 88:61-69

18. Brown RH (1978) A difference in $\mathrm{N}$ use efficiency in $\mathrm{C}_{3}$ and $\mathrm{C}_{4}$ plants and its implication in adaptation and evolution. Crop Sci 18:93-98

19. Morison JIL, Gifford RM (1983) Stomatal sensitivity to carbon dioxide and humidity. Plant Physiol 71:789-796

20. Hartman JC, Nippert JB, Springer CJ (2012) Ecotypic response of switchgrass to altered precipitation. Funct Plant Biol. doi:10.1071/ FP11229

21. Stout WL, Jung GA, Shaffer JA (1988) Effects of soil and nitrogen on water use efficiency of tall fescue and switchgrass under humid conditions. Soil Sci Soc Am J 52:429-434

22. Power JF (1985) Nitrogen- and water-use efficiency of several cool-season grasses receiving ammonium nitrate for 9 years. Agron J 77:189-192

23. Frank AB (1994) Physiological comparisons of crested wheatgrass and western wheatgrass to water. J Range Manage 47:460-466

24. Frank AB, Bauer A (1991) Rooting activity and water use during vegetative development of crested and western wheatgrass. Agron J 83:906-910

25. Jefferson PG, Cutforth HW (2005) Comparative forage yield, water use, and water use efficiency of alfalfa, crested wheatgrass and spring wheat in a semiarid climate in southern Saskatchewan. Can J Plant Sci 85:877-888

26. Bauder JW, Bauer A, Ramirez JM, Cassel DK (1978) Alfalfa water use and production on dryland and irrigated sandy loam. Agron J 70:95-99

27. Evans PS (1978) Plant root distribution and water use patterns of some pasture and crop species. New Zealand J Agric Res 21:216-265

28. Høgh-Jensen H, Schjoerring JK (1997) Interactions between white clover and ryegrass under contrasting nitrogen availability: $\mathrm{N}_{2}$ fixation, $\mathrm{N}$ fertilizer recovery, $\mathrm{N}$ transfer and water use efficiency. Plant Soil 1967:187-199

29. Bailey RG (1995) Description of the ecoregions of the United States (2nd Edition). Misc. Publ. 1931. USDA-Forest Service, Washington, DC USA

30. Ries RE, Zachmeier LG (1985) Automated rainout shelter for controlled water research. J Range Manage 38:353-357

31. Merrill SD, Tanaka DL, Krupinsky JM, Ries RE (2004) Water use and depletion by diverse crop species on Haplustoll soil in the Northern Great Plains. J Soil Water Conserv 59:176183

32. Littell RC, Milliken GA, Stroup WW, Wolfinger RD (1996) SAS Systems for mixed models. SAS Institute Inc. Cary, NC USA

33. Downes RW (1969) Differences in transpiration rates between tropical and temperate grasses under controlled conditions. Planta $88: 261-273$ 
34. Hofstra G, Hesketh JD (1969) Effects of temperature on the gas exchange of leaves in the light and dark. Planta 85:228-237

35. Koshi PT, Stubbendieck J, Eck HV, McCully WG (1982) Switchgrasses: forage yield, forage quality and water-use efficiency. J Range Manage 35:623-517

36. USDA-NRCS (2002) Soil survey of Morton County, North Dakota. Natural Resources Conservation Service, U.S. Department of Agriculture, Washington, DC

37. Monti A, Barbanti L, Zatta A, Zegada-Lizarazu W (2012) The contribution of switchgrass in reducing GHG emissions. GCB Bioenergy 4:420-434

38. Tufekcioglu A, Raich JW, Isenhart TM, Schultz RC (1999) Fine root dynamics, coarse root biomass, root distribution, and soil respiration in a multispecies riparian buffer in Central Iowa, USA. Agrofor Syst 44:163-174

39. Liebig MA, Johnson HA, Hanson JD, Frank AB (2005) Soil carbon under switchgrass stands and cultivated cropland. Biomass Bioenerg 28:347-354
40. Jackson RB, Sala OE, Field CB, Mooney HA (1994) $\mathrm{CO}_{2}$ alters water use, carbon gain, and yield for the dominant species in a natural grassland. Oecologia 98:257-262

41. Irigoyen JJ, Emerich DW, Sanchez-Diaz M (1992) Alfalfa leaf senescence induced by drought stress; photosynthesis, hydrogen peroxide metabolism, lipid peroxidatioan and ethylene evolution. Physiol Plant 84:67-72

42. Eissenstat DM, Yanai RD (1997) The ecology of root lifespan. In: Begon M, Fitter AH (eds) Advances in ecological research, 27th edn. Academic, San Diego, pp 1-60

43. Huang B, Gao H (2000) Root physiological characteristics associated with drought resistance in tall fescue cultivars. Crop Sci 40:196-203

44. Goins GD, Russelle MP (1996) Fine root demography in alfalfa (Medicago sativa L.). Plant Soil 185:281-291

45. Luo Y, Meyerhoff PA, Loomis RS (1995) Seasonal patterns and vertical distributions of fine roots of alfalfa (Medicago sativa L.). Field Crops Res 40:119-127 